\title{
Effect of Pruning Intensities and Fruit Load on Yield and Quality of Guava under High Density Planting System
}

\author{
Guguloth Lakpathi* and Matta Rajkumar \\ Fruit Research Station (FRS), Dr.YSR Horticultural Unversity, Sangareddy - 502 001, \\ Telangana state, India \\ *Corresponding author
}

\section{A B S T R A C T}

\section{Keywords}

Guava, Pruning intensities, Fruit load, Yield, Fruit quality

Article Info

Accepted:

16 April 2018

Available Online:

10 May 2018
Pruning of guava cv. Allahabad Safeda under high density planting was done in the third week of June, 2013 with three pruning intensities i.e. leaving $10 \mathrm{~cm}, 20 \mathrm{~cm}$ and $30 \mathrm{~cm}$ from base of the shoot and retaining 30, 40 and 50 fruits per tree. Ten centimeter $(10 \mathrm{~cm})$ pruning intensity has advanced the vegetative bud appearance, maximum fruit diameter at harvest, average fruit weight and fruit yield. Pruning intensity of $30 \mathrm{~cm}$ has increased the number of vegetative buds per pruned shoot and number new shoots per pruned shoot along with early harvesting at colour turning stage. Thirty (30) fruit load per tree recorded the minimum number of days taken for harvesting at colour turning stage and maximum average fruit weight at harvest. Maximum fruit yield was noticed with 50 fruit load per tree. The interaction between pruning intensity and fruit load has shown that maximum fruit diameter was recorded with $10 \mathrm{~cm}$ pruning intensity with 30 fruit load per tree. However, minimum number of days was taken for harvesting at colour turning stage with $30 \mathrm{~cm}$ pruning intensity in combination with 30 fruit load. However, the quality of fruits in control and other treatments was also at par.

\section{Introduction}

Guava (Psidium guajava L.) the "poor man's fruit" and "apple of tropics" is a popular fruit tree of tropical and sub-tropical climate and is native to the Tropical America stretching from Mexico to Peru. It belongs to the family Myrtaceae and has the recognition of being the most widely cultivated species of this family (Gadgil and Gadgil, 1933). Guava is considered as one of the exquisite, nutritionally valuable and remunerative fruit crop. Guava fruit is known for its 'vitamin-C', minerals like calcium, iron and phosphorous with pleasant aroma and flavour (Ulemale and Tambe, 2015). It excels most other fruit crops in productivity, hardiness, adaptability and nutritive value. Guava bears on current season's growth and flowers appear in the axils of new leaves, therefore, it responds well to pruning. Pruning of guava is one of the most important practices that influence the vigor, productivity and quality of the fruits (Gadgil and Gadgil, 1933). Large trees take several years before they come into bearing and overall cost of production per unit area is further increased. Hence, there is over riding need to improve the existing planting system 
and to manipulate tree growth using canopy management to control tree growth patterns, tree shape and maintaining high fruit production of desired size and quality (Gorakh Singh, 2001).

Jadhav et al., (2002) noticed that earliest emergence of vegetative bud sprout, shoot length, number of flowers per shoot and number of fruits per shoot, on severely pruned $(60 \mathrm{~cm})$ trees of guava was found to be significantly more than mild pruned $(30 \mathrm{~cm})$ trees and control. Rupankar Bhagawati et al., (2015) opined that severely pruned shoot of Guava have fewer number of shoots per pruned shoot. This might be due to less number of vegetative buds in severely pruned shoot. While the new shoots per shoot was lowest in shoots without pruning.

Sheikh and Rao (2002) found that highest fruit diameter of pomegranate was noticed in severe pruning as compared to mild pruning and control. Bikash Das (2014) reported that an alteration in the rooting pattern as influenced by shoot pruning in litchi. Shoot pruning resulted in lower biomass and carbohydrate allocation towards thicker roots. Sanjay Kumar Singh et al., (2010) noticed that under high density planting condition, fruit weight of mango was significantly influenced by pruning intensity and was highest in the lightly pruned trees. Average fruit weight decreased in the 'on' year due to increase in the number of fruits per tree. Number of fruits per tree was highest in the moderately pruned trees. Fruit volume increased in the severely pruned trees.

Madhubala Thakre et al., (2016) opined that sink strength (Guava fruit) is the ability to attract metabolite from different sources and decides the direction of flow of photoassimilates. Sink strength determined by the growth rate (sink activity) and the size of the sinks. By adopting partial removal of fruits, the existing leaf area was supporting less number of developing fruits, making more photosynthates available for each fruit unit, leading to increased fruit size.

Shweta Hiremath et al., (2017) reported that light pruning of Guava which might have increased the reproductive growth compared to unpruned plants which gave rise to more vegetative growth, Further there is possibility that the zone of flowering/fruiting buds in guava may be located at this length of shoot (10-15 cm from tip of shoot) thereby resulting in more flowering and fruit set in these plants. Pruning decreased the fruit load and as the number of fruits was less, the available food material reached the individual fruit in sufficient quantity.

Patel et al., (2014) noticed that increase in fruit weight might be due to the reduction in the number of Litchi fruits per tree thereby increasing the availability of photosynthates and lesser nutritional competition among the developing fruits, thus improving the fruit weight. The increase in fruit length and breadth might be due to the reduction in the number of fruits per tree thereby increasing the size of the cell and cell elongation which resulted in maximum accumulation of the food materials in the developing fruits, thus improving the fruit size.

Shaban and Haseeb (2009) opined that guava moderate pruning gave highest significant increase in the yield for the seasons, severe pruning and pinching gave a significant intermediate effect between moderate pruning and the control.

Sathya Prakash et al., (2012) opined that the moderately pruned guava trees in winter season produced fruits of largest size and of maximum weight and such fruits had highest TSS and ascorbic acid content. Smallest size and minimum weight with lowest TSS and 
ascorbic acid content was recorded in fruits harvested from unpruned control trees.

Meland (2009) stated that apple fruit weights and soluble solids contents values were highest with the lowest crop load and decreased with increasing crop load. Trees with the highest crop load had the lowest crop load in the following year. Fruit quality was generally high for all treatments.

The guava trees left unpruned, they tend to prolong the vegetative growth, reduced bearing area and finally branches become unproductive. Hence, to check growth and also to get fresh vegetative growth, pruning becomes essential cultural practice in fruit crops (Jawadagi et al., 1996). Fruit trees will often set more fruit than is needed for a full crop. Excessive fruit set often will result in small fruit with poor quality. Thinning in the early stages of fruit growth increases size of remaining fruits, reduces trunk breakage, and promotes regular bearing. Hand thinning is the most common procedure for guava since chemical thinning agents have not yet been worked out. As a result of fruit thinning, the fruit quality of the winter crop got improved producing more sugars, TSS and ascorbic acid whereas acidity of the fruit was decreased. Fruit set, fruit size, fruit weight and organoleptic values were also found improved as compared to control. Flowers and fruits of thinned plants showed less drop than control (Tahir and Kamran Hamid, 2002).

However, organized research work in these lines has not been carried out and hence the present study entitled "Effect of pruning levels and fruit load on growth, yield and fruit quality of guava (Psidium guajava L.) cv. Allahabad Safeda under high density planting" is proposed with the following objectives: 1 . To study the effect of pruning levels on growth, yield and fruit quality of guava under high density planting. 2 . To study the effect of fruit load on yield and fruit quality of guava under high density planting.

\section{Materials and Methods}

The experiment was carried out during the period from June, 2013 to January, 2014 at Fruit Research Station (FRS), Sangareddy, Medak district, Dr. YSRHU, on two and half year old trees of cv. Allahabad Safeda having uniform growth and vigour planted at a spacing of $2.5 \times 2.5 \mathrm{~m}$ under high density planting were selected. First and Second order shoots were pruned (except unpruned control trees) with help of secateur in june before bud opening stage comprised of treatments, viz. (a) $10 \mathrm{~cm}$, (b) $20 \mathrm{~cm}$ and (c) $30 \mathrm{~cm}$ from the base of the shoot orders. The experiment was laid out in the factorial RBD with 19 treatments with 2 replications and three trees per replication. The observations recorded are number of days taken for first vegetative bud appearance, number of vegetative buds sprouted per pruned shoot, fruit diameter, average fruit weight, fruit yield and fruit quality. The data were subjected to analysis of variance given in Panse and Sukhatme (1967). Significance was tested by ' $F$ ' value at 5 per cent level of probability. Critical difference (CD) values were calculated wherever the $\mathrm{F}$ test was found to be significant.

\section{Results and Discussion}

The number of days taken to first vegetative bud appearance of guava cv. Allahabad Safeda was significantly influenced by pruning intensity only. Among the pruning intensities studied, early vegetative bud appearance was observed with $10 \mathrm{~cm}$ (4.09 days) followed by $30 \mathrm{~cm}$ (4.44 days) and $20 \mathrm{~cm}$ (4.71 days) which differed significantly. The earliest vegetative bud emergence in the guava trees which were pruned severely. Similar, results were noticed by Suleman Mohammed (2006), Jadhav et al., (2002) in guava. It might be due 
to more reserve food materials available to individual vegetative bud (Syamal and Rajput, 1989) and more light interception in trees will induce early sprouting of vegetative buds. According to Mika (1986) the beneficial effect of mango pruning on the bearing is attributed to the removal of apical dominance, release of buds from correlative inhibition and wellfunctioning of the communication system within the trees.

Among the three pruning intensities studied, maximum number of new shoots per pruned shoot (6.82) was recorded with $30 \mathrm{~cm}$ pruning intensity which was significantly superior to $20 \mathrm{~cm} \mathrm{(5.65)} \mathrm{and} 10 \mathrm{~cm} \mathrm{(4.31).} \mathrm{Severely}$ pruned trees there were fewer number of new shoots per pruned shoot. As the number of new shoots per pruned shoot was reduced with increase in the severity in Guava (Madhubala Thakre et al., 2016), in phalsa (Naram naidu, 1987) and in apple (Gardener et al., 1922). It might be due to less number of vegetative buds left on the severe pruned shoot. The control recorded the minimum number of new shoot per pruned shoot (2.96) than all other treatments.

Among the pruning intensities studied, Maximum fruit diameter at the time of harvest $(7.45 \mathrm{~cm})$ was recorded with $10 \mathrm{~cm}$ pruning which was significantly superior to $30 \mathrm{~cm}$ pruning $(7.19 \mathrm{~cm})$ and $20 \mathrm{~cm}$ pruning $(7.17$ $\mathrm{cm})$. Similar results were noticed earlier by Syamal and Rajput (1989) in ber and Sheikh and Rao (2002) in pomegranate. The combination of $10 \mathrm{~cm}$ pruning intensity with 30 fruits pre tree has recorded maximum fruit diameter $(7.87 \mathrm{~cm})$ (Fig. 1) which was significantly superior to all other treatments followed by $20 \mathrm{~cm}$ with 40 fruit load (7.30 $\mathrm{cm})$. Sheikh and Rao (2002) found that the highest fruit diameter and fruit weight were noticed with severe pruning and 30 fruit load against mild pruning and 50 fruits load in pomegranate. Sathya Prakash et al., (2012) opined that guava fruit size has direct correlation with number of fruits borne on the trees.

The minimum number of days taken for harvesting at colour turning stage (104.71) was recorded with $30 \mathrm{~cm}$ pruning which was significantly superior to $10 \mathrm{~cm}$ pruning (114.24 days) and $20 \mathrm{~cm}$ pruning level (114.25 days). These results are in agreement with those of Naram Naidu (1987) who has reported that fruit maturity was delayed with increased severity of pruning in phalsa. This may be due to the reason that early flowering in light pruning treatments resulted in early maturity. Minimum number of days taken for harvesting at colour turning stage (107.03) was recorded with 30 fruit load followed by 50 fruit load (111.43 days) which differed significantly. Compared with high crop load trees, fruit from low crop load trees showed advanced maturity at harvest was reported by Jens et al., (2005) in apple and Abeer and Mohsen (2010) in peach. The combination of $30 \mathrm{~cm}$ pruning intensity with 30 fruit load has recorded minimum number of days taken for harvesting at colour turning stage (91.21) which was significantly superior to $30 \mathrm{~cm}$ pruning with 50 fruit load (109.94 days) and $20 \mathrm{~cm}$ pruning with 50 fruit load (112.15 days).

The maximum average fruit weight at harvest $(270.26 \mathrm{~g})$ was recorded with $10 \mathrm{~cm}$ pruning followed by $30 \mathrm{~cm}$ pruning $(242.58 \mathrm{~g})$ which differed significantly. Maximum fruit weight was obtained with severe pruning. Similar, results were noticed earlier by Shaik and Hulmani (1993) in guava, Bhanu Pratap et al., (2009) in mango and Syamal and Rajput (1989) in ber. The increase in weight could be due to utilization of whole food materials among the fewer fruits recorded under sever pruned trees. Similar results are obtained earlier by Shweta Hiremath et al., (2017) and Bajpai et al., (1973) in guava. 


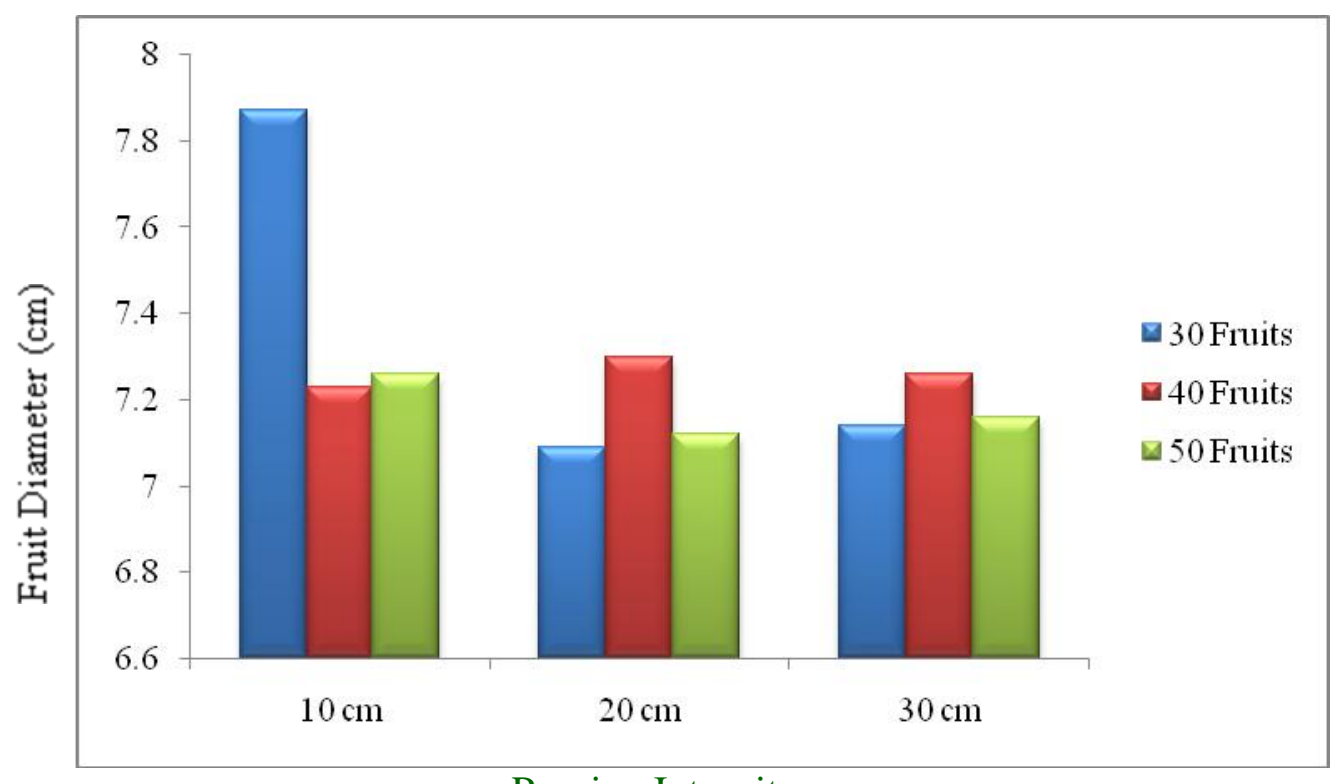

Pruning Intensity

Maximum average fruit weight at harvest $(253.55 \mathrm{~g})$ was recorded with 30 fruit load which was on par with 40 fruits load (244.84 g) followed by 50 fruit load (235.26 g). Sathya Prakash et al., (2012) opined that guava fruit size has direct correlation with number of fruits borne on the trees. Owing to high leaf to fruit ratio and availability of more photosynthates due to removal of current season's growth, the fruits gained larger size and weight compared to those from unpruned trees. Similar, results were noticed by Madhubala Thakre et al., (2016) and Patel et al., (2014) in Guava.

The maximum fruit yield per tree $(10.66 \mathrm{~kg})$ was recorded with $10 \mathrm{~cm}$ pruning followed by $30 \mathrm{~cm}$ pruning $(9.68 \mathrm{~kg} /$ tree $)$ which differed significantly. Sathya Prakash et al., (2012) noted that highest fruit yield per tree was obtained with severely pruned trees of guava. Chandra and Govind (1995) noticed that pruning intensities in high density plantation of guava, showed that the highest fruit yield was obtained with above 70 per cent pruning intensity but the fruit weight was reduced by pruning intensities above 25 per cent. Rajendra et al., (1980) reported that increase in the severity of pruning increased the total yield per tree by way of producing bigger fruits in apple. Gorakh Singh (2011) reported that maximum yield was recorded with pruning under high density planting in guava compared to control trees. It is due to more light interception within tree canopies as a result of pruning. Maximum fruit yield per tree $(11.76 \mathrm{~kg})$ was recorded with 50 fruit load followed by 40 fruit load $(9.79 \mathrm{~kg} /$ tree $)$ and they differed significantly. Sdoodee et al., (2008) reported that the highest yield was found in high crop load mangosteen trees. Yuri et al., (2011) found that mean fruit weight of apple decreased with increasing fruit crop load.

Fruit quality was generally high for all treatments which were on par with control fruits. These findings are in agreement with the findings of Meland (2009) in apple crop load. Fruit number did not affect soluble solid content or acidity of grape (Moon dooYoung and Lee Don Kyun, 1996). But fruit yield was significantly increased without affecting the fruit quality through pruning and fruit load in high density planting of guava.

It can be concluded that, pruning of $10 \mathrm{~cm}$ is suitable for commercial fruit production as 
the growers are more concerned with early vegetative bud appearance, number of vegetative buds per pruned shoot, cumulative length of new shoots and fruit yield. Pruning intensity of $30 \mathrm{~cm}$ can be utilized for maximum number of new shoots per pruned shoot, advancement of flowering and time of harvesting for capturing early market with increased fruit yield. Retaining 50 fruits per tree can result in maximum fruit yield with good quality fruits. However, the quality of fruits in control and other treatments was at par with each other. From the results, it is very clear that the growth, yield and fruit quality of guava for commercial production can be manipulated easily by horticultural practices like pruning and restricted fruit load per tree for good yield depending upon the situation.

\section{Acknowledgement}

The first author is greatful to the Fruit Research Station (FRS) Sangareddy. (Dr Y S $\mathrm{R} \quad$ Horticulture University, Venatramanngudem) for providing the financial assistance in the form of junior input and workers to carry out this research.

\section{References}

Abeer and Mohsen. 2010. Thinning time and fruit spacing influence on maturity, yield and fruit quality of peaches. Journal of Horticultural Science \& Ornamental plants. 2(3): 79-87.

Bajpai, P.N, Shukla, H.S. and Chathurvedi, A.M. 1973. Effect of pruning on growth, yield and quality of guava (Psidium guajava L.) cv. Allahabad Safeda. Progressive Horticulture. 5(1): 73-79.

Bhanu Pratap, Singh, S.K, Singh, H.K, Gaurav, S.S. and Shashi Bala. 2009. Effect of pruning on physico-chemical properties of mango cv. Amrapali under high density orcharding. Annals of Horticulture. 2(1): 62-64.

Bikash das. 2014. Impact of shoot pruning on root distribution pattern of litchi (Litchi chinensis sonn.). The Bioscan. 9(1): 5153.

Chandra, R. and Govind, S. 1995. Influence of time and intensity of pruning on growth, yield and fruit quality of guava under high density planting. Tropical Agriculture. 72(2): 110-113.

Gadgil, D.R. and Gadgil V.R, 1933. A survey of the marketing of fruit in Poona. Gokhale Inst. Politics and Economics Publi. : 3 .

Gardner, V.R, Bradford, C.F. and Hooker, H.D. 1922. The fundamentals of fruit production. pp 408-418. McGraw Hill, New York.

Gorakh Singh. 2001. High density planting in guava. Annual Report, Central Institute of Subtropical Horticulture, Lucknow.

Gorakh Singh. 2011. Application of canopy architecture in high density planting in guava. Progressive Horticulture. 43(1): 36-43.

Jadhav, B.J, Mahurkar, V.K. and Kale, V.S. 2002. Effect of time and severity of pruning on growth and yield of guava (Psidium guajava L.) cv. Sardar. Orissa Journal of Horticulture. 2002. 30: 2, 83-86.

Jens, N, Dennis, H. G, William, A.L. and John, W.P. 2005. Physiological and biochemical leaf and tree responses to crop load in apple. Tree Physiology. 25: 1253-1263.

Madhubala Thakre, Shant Lal, Shweta Uniyal, Amit Kumar Goswami and Pratibha Prakash. 2016. Pruning for crop regulation in high density guava (Psidium guajava L.) plantation. Spanish Journal of Agricultural Research. 14(2), e0905, 8 pages.

Meland, M. 2009. Effects of different crop loads and thinning times on yield, fruit 
quality, and return bloom in Malus $\mathrm{x}$ domestica Borkh. 'Elstar'. Journal of Horticultural Science and Biotechnology. 84: Special Issue, 117121.

Mika, A. 1986. Physiological responces of fruit trees to pruning. In: Horticulture Review (ed) J. Janik. Vol 8, AVI Publishing House, West Port pp 337378.

MoonDooYoung and LeeDonKyun. 1996. Effects of berry thinning on fruit quality of grape "Fujiminori" in plastic film house. $R D A$ Journal of Agricultural Science, Horticulture. 38: (1) 683-686.

Naram Naidu, L. 1987. Studies on the effect of time and severity of pruning on phalsa (Grewia asiatica L.) M.Sc. (Ag.) Thesis submitted to Andhra Pradesh Agricultural University, Hyderabad.

Panse, V.G. and Sukhatme, P.V. 1967. Statistical methods for agricultural workers. Indian Council for Agricultural Research (ICAR), New Delhi, India.

Patel, R. K, Meitei, S.B, Kumar1, A, Srivastava, K, Deka, B.C, Deshmukh, N.A, and Verma, V.K. 2014. Effect of leaf and fruit thinning on yield and quality of peach cv. Flordasun. The Ecoscan Special issue, Vol. VI: 467471.

Rajendra, P, Srivasthava and Ram Kumar. 1980. Pruning young apple trees. Indian Journal of Horticulture. Pp. 7-10.

Rupankar Bhagawati, Kaushik Bhagawati, Vijay Kumar Choudhary, Deep Jyoti Rajkhowa and Rupjyoti Sharma. 2015. Effect of Pruning Intensities on the Performance of Fruit Plants under MidHill Condition of Eastern Himalayas: Case Study on Guava. International Letters of Natural Sciences. Vol. 46. pp 46-51.
Sanjay Kumar Singh, Singh, S.K. and Sharma, R.R. 2010. Pruning alters fruit quality of mango cultivars (Mangifera indica L.) under high density planting. Journal of Tropical Agriculture. 48 (12): 55-57.

Satya Prakash, Virendra Kumar, Saroj, P.L. and Sirohi, S.C. 2012. Response of yield and quality of winter guava to severity of summer pruning. Indian Journal of Horticulture. 69(2): 173-176.

Sdoodee, S, Phonrong, K. and Ruongying, Y. 2008. Mangosteen crop load affects physiological responses, fruit yield and fruit quality. Acta Horticulturae. 773, 187-194.

Shaban, A.E.A. and Haseeb, G.M.M. 2009. Effect of Pruning Severity and Spraying some Chemical Substances on Growth and Fruiting of Guava Trees. AmericanEurasian journal of Agriculture \& Environmental Science. 5 (6): 825-831.

Shaikh, M.K. and Hulamani, N.C. 1993. Effect of severity of pruning on flowering and fruiting of guava (Psidium guajava L.) cultivar Navalur. Progressive Horticulture. 25(3-4): 157160.

Sheikh, M.K. and Rao, M.M. 2002. Effect of pruning and fruit load on yield and quality in pomegranate (Punica granatum L.) Var. Ganesh. Karnataka Journal of Agricultural Sciences. 15: 3, 549-555.

Shweta Hiremath, Athani, S.I, Kishore Kumar Das, Choudhury, P.R, Deepa Pujar, Shirol, A.M, and Gopali, J.B. 2017. International Journal of Chemical Studies. 5(6): 289-293.

Suleman Mohammed, Sharma, J.R, Ranjeet Kumar, Gupta, R.B. and Sultan Singh. 2006. Effect of pruning on growth and cropping pattern in guava cv. Lucknow49. Haryana Journal of Horticultural Sciences. 35: 3/4, 211-212. 
Syamal, M.M. and Rajput, C.B.S. 1989. Effect of pruning on growth, fruiting and quality of ber (Zizyphus mauritiana Lamk.). Indian Journal of Horticulture. 46(3): 364-367.

Tahir F.M. and Kamran Hamid. 2002. Studies of Physico-chemical Changes due to Fruit Thinning in Guava (Psidium guajava L.). OnLine Journal of Biological Sciences. 2(11): 744-745.
Ulemale, P.H and Tambe, T.B. 2015. Variability in growth parameters of red fleshed and white fleshed guava genotypes. The Bioscan. 10(2): 885887.

Yuri, J.A, Gonzalez Talice, J, Verdugo, J. and Pozo, A. del. 2011. Responses of fruit growth, quality, and productivity to crop load in apple cv. Ultra Red Gala/MM111. Scientia Horticulture. 127: 3, 305-312.

\section{How to cite this article:}

Guguloth Lakpathi and Matta Rajkumar. 2018. Effect of Pruning Intensities and Fruit Load on Yield and Quality of Guava under High Density Planting System. Int.J.Curr.Microbiol.App.Sci.

7(05): 1853-1860. doi: https://doi.org/10.20546/ijcmas.2018.705.218 